\title{
Giant basal cell carcinoma of scalp: A neglected tumor and twenty-five years after diagnosis - case report and literature review
}

\author{
Ali Koyuncuer \\ Department of Pathology, Antakya State Hospital, Hatay, Turkey \\ Correspondence: Ali Koyuncuer. Address: Department of Pathology, Antakya State Hospital, Hatay, Turkey. E-mail: \\ alikoyuncuer@hotmail.com
}

Received: November 9, 2014

DOI : $10.5430 /$ crcp.v2n2p22

Accepted: December 7, 2014

Online Published: December 9, 2014

URL: http://dx.doi.org/10.5430/crcp.v2n2p22

\begin{abstract}
Basal cell carcinoma (BCC) is the most common non-melanoma skin cancers, Giant variant of BCCs are a rare cutaneous neoplasms. The most important risk factors for skin cancers are ultraviolet (UV) exposure. We report the case of a 69-year-old men presented with pruritus, bleeding, focal ulcerated, large multinodular lesion symptoms and findings in the temporal region of the scalp. Grossly, there was an well-demarcated relatively smooth discrete mass measuring tumor of $5.5 \mathrm{~cm} \times 4.5 \mathrm{~cm}$. The histopathological diagnosis was Giant BCC. A review of the literature on Giant BCCs are rare variant in the skin of previously described cases. This tumor most frequently involves in the back, the face, and extremity. Risk factors that have been associated with skin in include smoking, prior radiation exposure, neglect and development of Giant BCCs. Clinical course of the disease are generally more aggressive. The treatment of choice is complete surgical excision, reconstruction and is curative.
\end{abstract}

\section{Key words}

Basal cell carcinoma, Giant, Neglect, Scalp

\section{Introduction}

Nonmelanoma skin cancers are most prevalent cutaneous malignant neoplasm in the United States an estimated incidence two million cases per year ${ }^{[1]}$. Basal cell carcinoma $(\mathrm{BCC})$ is the most common skin malignant tumors ${ }^{[2]}$. BCC is overwhelming majority of patients related to prolonged exposure to sun and relatively low doses ${ }^{[3]}$. Other proposed clinical parameters that may be associated with increased risk for the development of BCC include genetic factors (skin type, eye/hair colour ${ }^{[4]}$, socioeconomic status ${ }^{[5]}$ family history, freckle in childhood, outdoor work, immunosuppressed cases and previous radiation treatment for the malignancies ${ }^{[6]}$. BCC is more common older men than women ${ }^{[7]}$ and mean age at presentation is 65 years ${ }^{[8]}$. Neoplasm occur most commonly on the face and are often single, can range in diameters from a few millimeters to several centimeters in diameter (range $2 \mathrm{~mm}$ to $15 \mathrm{~mm}{ }^{[2]}$. Less frequently, neck, trunk, extremities may be seen in other regions of the body ${ }^{[9]}$. Giant BCCs are a rare cutaneous neoplasms with by definiton lesion size $5 \mathrm{~cm}$ more in greater diameter and about $0.5 \%-1 \%$ of all BCCs fall into the giant category ${ }^{[10]}$. It presents most often on the trunk, and is occasionally associated with metastases, mortality or neglect ${ }^{[9]}$. 


\section{Case presentation}

\subsection{Clinical data and presentation}

A 69-year-old man presented with pruritus, bleeding, focal ulcerated, large multinodular lesion symptoms and findings in the temporal region of the scalpto the department of plastic surgery of a state hospital. He noted that the lesion had a 25 years history and the tumour quickly growing in the last two month period. The clinical impression was that the lesion represented malingnant tumor. The patient underwent the lesion scalp excised.

\subsection{Histopathological findings}

\subsubsection{Macroscopic appearance}

The specimen was collected from the scalp and consisted of a excised of specimen measuring $7 \mathrm{~cm}$ in length $6 \mathrm{~cm}$ in average diameter ( $0.5 \mathrm{~mm}-1 \mathrm{~cm}$ peripheral margins, $1 \mathrm{~cm}$ deep margins) after fixation in $10 \%$ neutral buffered formalin. A serial section of the scalp skin specimen of patient did not reveal infiltrative tumors in the deep compartment. Gross findings of the present on this patient's scalp tissues showed focal ulcerated, large multinodular lesions features and gray-pink firm noninfiltration, and a well-localized, well-demarcated relatively smooth discrete mass measuring $5.5 \mathrm{~cm} \times$ $4.5 \mathrm{~cm}$. The cut surface section of the lesion had a gray or white, nodular and relatively regular border appearance (see Figure 1).

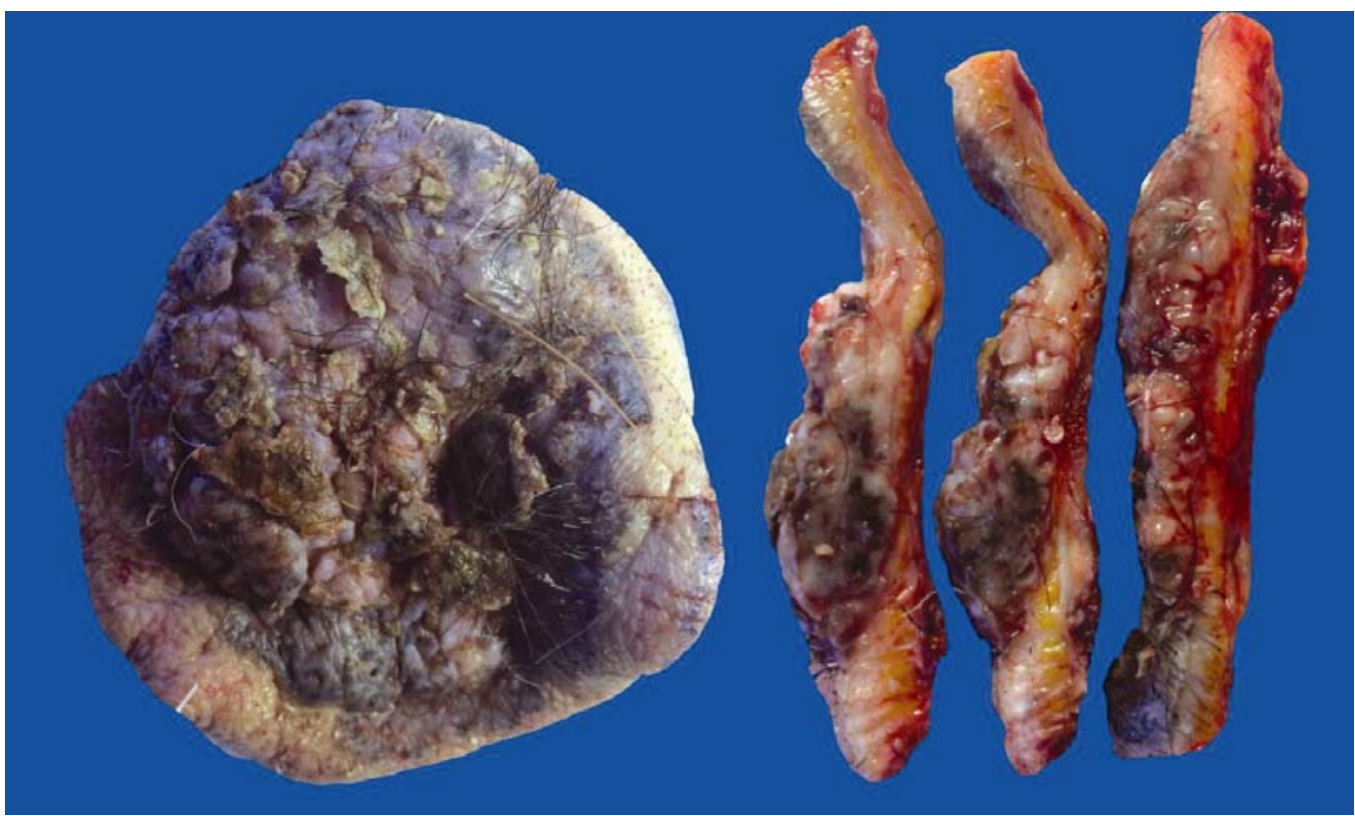

Figure 1. Basal cell carcinoma (BCC): Focal ulcerated, nodular lesions are present on this patient's scalp

\subsubsection{Microscopic features}

Histologically, the tumor appeared to predominantly consist of lobules of basaloid cells with scant cytoplasm and a characteristic outer palisade of cells related with a surrounding loose fibrous and inflammatory stroma surrounding islands. The tumor had a prominent ulceration, apoptosis, relatively abundant mitoses, retraction artifact spaces, well circumscribed tumor lobules (nodular), melanin is present within in stromal macrophages (pigmented) and lymphocytes, plasma cells formed small aggregates of collagenized or dense fibrous stroma background. Necrosis, marked pleomorphism, squamous differentiation, mucin, perineural invasion and skull erosionwere not present. The tumor cells were positive for CK5/6 and weakly positive Bcl-2 and negative for antibodies to p53 (see Figure 2). 


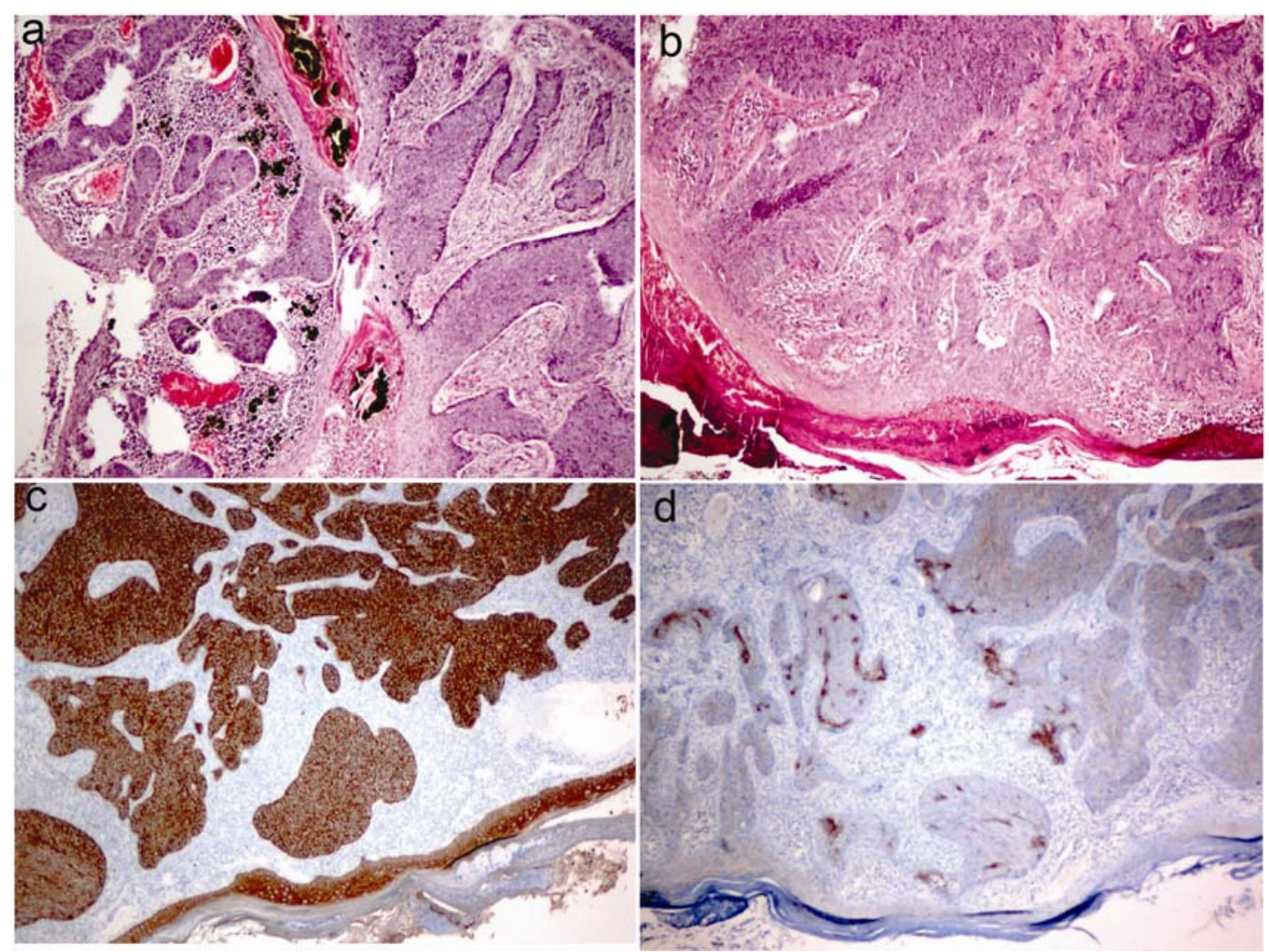

Figure 2. ( $\mathrm{a}, \mathrm{b})$ Basal cell carcinoma (BCC). Consists of ulcerative lesion a two population of a collagenized or dense fibrous stroma background surrounding islands remninscent of the basal cell of the epidermis and hair follicle, both dendritic melanocytes or stromal macrophages. (c) CK5/6; the presence of is confirmed with strong and diffuse positive of CK5/6 immunohistochemistry. (d) Bcl-2; how patchy and weak staining with this antibody in the carcinoma.

\section{Discussion}

Giant BCCs of the skin are defined as a lesion measuring $5 \mathrm{~cm}$ larger in diameter ${ }^{[10]}$. Therefore, some authors have suggested that lesions diameter defined as $10 \mathrm{~cm}$ or more variant of giant ${ }^{[7,9]}$. Giant BCCs are rare variant in the skin ${ }^{[11]}$ and clinical behavior is generally more aggressive with local invasion and distant metastasis has been reported ${ }^{[12]}$. Manstein et al. reported Giant BCC with no observed distant metastasis ${ }^{[13]}$. Associated with an increased risk of metastasis included tumors larger than $5 \mathrm{~cm}$ in diameter that risk over $25 \%{ }^{[14]}$. In most cases the etiopathogenesis of skin cancers appear priority was ultraviolet (UV) exposure ${ }^{[15]}$. Suggested risk factors in such cases include biologically aggressive subtype, a history of previous radiation and neglect. Smith et al. reported the prevalence of the BCC more than $1.0 \mathrm{~cm}$ in size is associated with higher in cigarette simoking ${ }^{[16]}$. In addition to related history alcoholism and deficiency of iron ${ }^{[17]}$. In our case there was previous history alcohol and cigarette smoked 10 cigarettes $(1 / 2$ pack) per day for 20 years. Archontaki et al. was observed most frequently located in the back (27.5\%), the face (23.5\%), extremity (13.7\%), less frequently scalp or genital orgin $(5.9 \%)^{[10]}$ (see the table). Most patients are old aged $>65$ years (mean age at presentation, 67 years; range, 43-84 years). There is male predilection $(2: 1)^{[10]}$. Giant varyant BCC infiltration bone, muscle and cartilage invasion is occasionally seen ${ }^{[14]}$. Morpheaform, metatypical, and infiltrative histological subtypes are associated with high recurrence rates ${ }^{[9]}$. In our case, the tumor appears limited to a epidermis and dermis with no observed spread to the adjacent tissues. Bcl-2 and is significantly higher expression having been documented in from $81.2 \%$ of cases. p53 protein is positive in $40.6 \%$ of cases ${ }^{[18]}$. Plump et al. reported BCC express CK 5/6 as well as positive in 28 of cases and cutaneous adnexal neoplasms is positive CK $5 / 6$ in $97 \%$ of cases ${ }^{[19]}$. The pathological differential diagnosis of BCC includes trichoblastoma, merkel cell carcinoma, squamous cell carcinoma with basaloid features and microcystic adnexal 
carcinoma ${ }^{[20]}$. Treatment of these lesions should be by widely complete excision with at least $1.0 \mathrm{~cm}$ margin and close follow-up. The treatment of choice is complete surgical excision, reconstruction and is curative ${ }^{[21]}$. In addition, Rossi et al. reported favorable with adequate surgical treatment and radiotherapy ${ }^{[22]}$.

Table. Age, gender, anatomical distribution and defined in years of giant $\mathrm{BCC}{ }^{[23-26]}$

\begin{tabular}{lllll}
\hline Author/References & Year & Age (years) & Gender & Site \\
\hline Fresini A & 2007 & 72 & Men & Back \\
RiegerUM & 2009 & 67 & Men & Left clavicle \\
Bogdanić B & 2009 & 71 & Women & Back \\
Sakalauskaite M & 2009 & 69 & Women & Occipital region \\
Handjani F & 2010 & 65 & Men & Leg \\
Heo YS & 2011 & 53 & Men & Scalp \\
Larsen AK & 2014 & 48 & Men & Scalp \\
\hline
\end{tabular}

\section{Conflict of interests}

The author declares that he has no conflict of interests.

\section{Ethical approval}

Written informed consent was obtained from the patient for publication of this case report and its accompanying images.

\section{References}

[1] Kim RH, Armstrong AW: Nonmelanoma skin cancer. Dermatol Clin. 2012; 30: 125-139. http://dx.doi.org/10.1016/j.det.2011.08.008

[2] Koyuncuer A. Histopathological evaluation of non-melanoma skin cancer. World J Surg Oncol. 2014 May 21 ; 12 : 159. http://dx.doi.org/10.1186/1477-7819-12-159

[3] Rosso S, Zanetti R, Martinez C, Tormo MJ, Schraub S, Sancho-Garnier H, et al. The multicentre south European study 'Helios'. II: Different sun exposure patterns in the aetiology of basal cell and squamous cell carcinomas of the skin. Br J Cancer. 1996; 73: 1447-1454. PMid: 8645596. http://dx.doi.org/10.1038/bjc.1996.275

[4] Lear JT, Tan BB, Smith AG, Bowers W, Jones PW, Heagerty AH, et al. Risk factors for basal cell carcinoma in the UK: case-control study in 806 patients. J R Soc Med. 1997 Jul; 90(7):371-4. PMid: 9290417.

[5] Kiiski V, de Vries E, Flohil SC, Bijl MJ, Hofman A, Stricker BH, et al. Risk factors for single and multiple basal cell carcinomas.

[6] Chinem VP, Miot HA. Epidemiology of basal cell carcinoma. An Bras Dermatol. 2011 Mar-Apr; 86(2): 292-305. PMid: 21603813. http://dx.doi.org/10.1590/S0365-05962011000200013

[7] Weedon D, Marks R, Kao GF, Harword CA. Keratinocytic Tumours. In World Health Organization Classification of Tumours. Pathology \& Genetics of Skin Tumours. Edited by LeBoit PE, Burg G, Weedon D, Sarasain A. Lyon: IARC Press; 2006; 9-47.

[8] Scrivener Y, Grosshans E, Cribier B. Variations of basal cell carcinomas according to gender, age, location and histopathological subtype. Br J Dermatol. 2002; 147: 41-47. PMid: 12100183. http://dx.doi.org/10.1046/j.1365-2133.2002.04804.x

[9] Calonje E, Brenn T, Lazar A, Mckee PH. Tumors of the surface epithelium. McKee's Pathology of the Skin with Clinical Correlations. 4th ed Saunders an imprint of Elsevier Limited. 2012; 1088-1106.

[10] Archontaki M, Stavrianos SD, Korkolis DP, Arnogiannaki N, Vassiliadis V, Liapakis IE, et al. Giant Basal cell carcinoma: clinicopathological analysis of 51 cases and review of the literature. Anticancer Res. 2009 Jul; 29(7): 2655-63. PMid: 19596942.

[11] Heo YS, Yoon JH, Choi JE, Ahn HH, Kye YC, Seo SH. A case of superficial giant Basal cell carcinoma with satellite lesions on scalp. Ann Dermatol. 2011 Sep; 23 Suppl 1: S111-5. Epub 2011. Sep 30. http://dx.doi.org/10.5021/ad.2011.23.S1.S111

[12] Nasser N, Nasser Filho N, Trauczynski Neto B, Silva LM. Giant basal cell carcinoma. An Bras Dermatol. 2012 May-Jun; 87(3): 469-71. PMid: 22714766. http://dx.doi.org/10.1590/S0365-05962012000300019

[13] Manstein CH, Gottlieb N, Manstein ME, Manstein G. Giant basal cell carcinoma: a series of seven T3 tumors without metastasis. Plast Reconstr Surg. 2000 Sep; 106(3): 653-6. PMid: 10987474. http://dx.doi.org/10.1097/00006534-200009010-00021

[14] Bogdanić B, Smud S, Bagatin D, Nola M, Mijatović D, Majerović M. Giant basal cell carcinoma of the back: a case report and review of the literature. Coll Antropol. 2009 Mar; 33(1): 315-8. PMid: 19408644. 
[15] Carøe TK, Ebbehøj NE, Wulf HC, Agner T. Occupational skin cancer may be underreported. Dan Med J. 2013 May; $60(5):$ A4624. PMid: 23673262.

[16] Smith JB, Randle HW. Giant basal cell carcinoma and cigarette smoking. Cutis. 2001 Jan; 67(1): 73-6. PMid: 11204609.

[17] Handjani F, Shahbaz S, Sari-Aslani F, Aghaei S, Ali-Zadeh AA. A giant polypoid basal cell carcinoma of the lower extremity. Arch Iran Med. 2010 Mar; 13(2): 153-5. PMid: 20187672.

[18] Yan L, Chen M, Yu G. Expression of bcl-2, bax and p53 protein in the basal cell carcinoma. Hunan Yi Ke Da Xue Xue Bao. 1999; 24(2): 179-80. PMid: 11938785.

[19] Plumb SJ, Argenyi ZB, Stone MS, De Young BR. Cytokeratin 5/6 immunostaining in cutaneous adnexal neoplasms and metastatic adenocarcinoma. Am J Dermatopathol. 2004 Dec; 26(6): 447-51. PMid: 15618924. http://dx.doi.org/10.1097/00000372-200412000-00001

[20] Prieto DG, Shea CR, Celebi JT, Busam KJ. Adnexal Tumors. Dermatopathology - edited by Klaus J. Busam - 1st ed (Foundations in diagnostic pathology). Saunders. 2010; 381-436.

[21] Lackey PL, Sargent LA, Wong L, Brzezienski M, Kennedy JW. Giant basal cell carcinoma surgical management and reconstructive challenges. Ann Plast Surg. 2007 Mar; 58(3): 250-4. PMid: 17471127. http://dx.doi.org/10.1097/01.sap.0000250842.96272.37

[22] Rossi R, Campolmi P, Giomi B, Massi D, Cappugi P. Giant exophytic basal cell carcinoma treated with radiotherapy. J Eur Acad Dermatol Venereol. 2002 Jul; 16(4): 374-6. PMid: 12224695. http://dx.doi.org/10.1046/j.1468-3083.2002.00571.x

[23] Rieger UM, Schlecker C, Pierer G, Haug M. Spontaneous regression of two giant basal cell carcinomas in a single patient after incomplete excision. Tumori. 2009; 95: 258-63. PMid: 19579878.

[24] Larsen, Anne Kristine, El-Charnoubi, Waseem-Asim Ghulam, Gehl, Julie, Krag, Christen. Neglected Giant Scalp Basal Cell Carcinoma. Plastic and Reconstructive Surgery - Global Open: March 2014; 2(3): e120. http://dx.doi.org/10.1097/GOX.0000000000000066

[25] M. Sakalauskaite, K. Vitkus, D. Balciunas, S. Sirsinaitis, S. Rocka. Invasive giant basal cell carcinoma of the head: case report, reconstruction choice and literature review. Central European Journal of Medicine. 2009; 4(4): 519-526. http://dx.doi.org/10.2478/s11536-009-0069-7

[26] Fresini A, Rossiello L, Severino BU, Del Prete M, Satriano RA. Giant basal cell carcinoma. Skinmed. 2007 Jul-Aug; 6(4): $204-5$. PMid: 17618177. http://dx.doi.org/10.1111/j.1540-9740.2007.06399.x 